\title{
The separation and simultaneous determination of V(IV) and V(V) species complexed with EDTA by IC-ICP-OES
}

\author{
PP Coetzee ${ }^{*}$, JL Fischer and Mingsong Hu \\ Department of Chemistry and Biochemistry, Rand Afrikaans University, PO Box 524, Auckland Park 2006, South Africa
}

\begin{abstract}
A method for the separation of $\mathrm{V}(\mathrm{IV})$ and $\mathrm{V}(\mathrm{V})$ in the form of the EDTA complexes using anion chromatography with a Dionex AG5 anion exchange guard column, and the simultaneous determination of $\mathrm{V}(\mathrm{IV})$ and $\mathrm{V}(\mathrm{V})$ by inductively coupled plasma optical emission spectrometery is described. The interference from other elements is negligible. The detection limits of V(IV) and V(V) were $0.02 \mathrm{mg} / \ell$ and $0.05 \mathrm{mg} / \ell$, respectively, using a glass nebuliser and $2 \mu \mathrm{g} / \ell$ for both species by using an ultrasonic nebuliser. The linear range was two orders of magnitude. The method was applied to the analysis of spiked water and industrial samples containing $\mathrm{V}$ in different oxidation states.
\end{abstract}

\section{Introduction}

$\mathrm{V}(\mathrm{IV})$ and $\mathrm{V}(\mathrm{V})$ species play an important role in many industrial and environmental processes. $\mathrm{V}$ and its compounds are used extensively in the steel and petrochemical industries. The South African petrochemical industry, for example, uses the Sulfolin and Benfield processes, based on the $\mathrm{V}(\mathrm{IV}) / \mathrm{V}(\mathrm{V})$ redox couple to remove sulphur and $\mathrm{CO}_{2}$, respectively, from process streams in the production of petrol and diesel from coal. Both species can exist in the environment but $\mathrm{V}(\mathrm{V})$ species are the most stable and also the most toxic (Browning, 1961; Cotton and Wilkinson, 1988). Other oxidation states such as V(II) and V(III) are not stable and will be oxidised to $\mathrm{V}(\mathrm{IV})$ and $\mathrm{V}(\mathrm{V})$ by atmospheric oxygen. Both V(IV) and $\mathrm{V}(\mathrm{V})$ species may find their way into the natural environment, in particular surface waters as toxic pollutants. V(IV) can be stabilised in natural waters by complexation with a variety of ligands, such as carboxylic acids.

In recent years $\mathrm{V}$-speciation studies have focused on the determination of V in natural waters, (Bosque-Sendra et al., 1998; Dupont et al., 1991; Miura, 1990; Yamane et al., 1998) biological systems (Elvingson et al., 1997; Hirayama et al., 1992; Kawakubo et al., 1995) and in industrial processes (De Beer and Coetzee, 1994; Murthy et al., 1989). A literature survey shows that most published analytical methods focus on the determination of total $\mathrm{V}$ or the determination of one species at a time. These methods include high performance liquid chromatography (De Beer and Coetzee, 1994; Komarova et al., 1991; Miura, 1990; Miura et al., 1990), spectrophotometry (Balaji et al., 1998; Bosque-Sendra et al., 1998; Chauhan and Kakkar, 1992; Iranpoor et al., 1992; Kawakubo et al., 1995; Murthy et al., 1989; Shah etal., 1991; Zucchi et al., 1998), flow injection (Grudpan and Nacapricha, 1991; Taylor et al., 1996; Yamane et al., 1998), atomic absorption spectrometery (Chakraborty and Das, 1994; Frankenberger et al., 1991; Yaman and Gucer, 1994), atomic emission spectrometery (Dupont et al., 1991; Hirayama et al., 1992), colorimetric (Serrat and Morell, 1994), and electrochemical methods (Ensafi and Naderi, 1997; Sander and Henze, 1996; Vukomanovic and Van Loon, 1994). Bosque-Serdra developed a method for V speciaton (Bosque-Sendra et al., 1998) based on the pre-

* To whom all correspondence should be addressed.

疋(011) 489-2558; fax: (011) 4892819; e-mail: ppc@na.rau.ac.za

Received 20 November 2000; accepted in revised form 16 October 2001. concentration of $\mathrm{V}(\mathrm{IV})$ in the first step and $\mathrm{V}(\mathrm{V})$ after reduction with ascorbic acid in the second step. Only a few methods are reported for the simultaneous measurement of V species (Murthy et al., 1989; De Beer and Coetzee, 1994; Komarova et al., 1991). Disadvantages of these methods include: low sensitivities, interference and lengthy procedures.

No general accepted or standard method for the simultaneous determination of vanadium species is currently available. This is particularly true for industrial samples with complex matrices and environmental samples with low concentrations of $\mathrm{V}$.

The aim of this work was to develop a simple, fast, costeffective, and interference-free method for the simultaneous determination of $\mathrm{V}(\mathrm{IV})$ and $\mathrm{V}(\mathrm{V})$ that would be useful in a routine industrial or water quality laboratory. This was achieved by using a hyphenated technique approach with ion chromatography inductively coupled plasma optical emission spectrometry (ICICP-OES). V(IV) and V(V) species were complexed with EDTA, separated on an anion exchange column using a modified carbonate and bicarbonate buffer spiked with EDTA as eluant, and quantitatively and element-specifically determined by ICP-OES.

\section{Experimental}

\section{Instrumentation}

\section{Ion chromatography}

A Dionex ion chromatography pump (2000i) and Waters injection system in conjunction with a Dionex guard column were used as the separation system. Three different guard columns, AG4, AG5 and AG14 were evaluated in this work.

Table1 lists the optimised chromatographic conditions for separation of $\mathrm{V}(\mathrm{IV})$ and $\mathrm{V}(\mathrm{V})$.

\begin{tabular}{|l|l|}
\hline \multicolumn{2}{|c|}{ OABLE 1 } \\
Optimised chromatographic conditions
\end{tabular}




\section{Inductively coupled plasma optical emission spectroscopy}

A Varian Liberty 110 ICP-OES spectrometer was used as a detector in the chromatography system. ICP-OES conditions are summarised in Table 2. Ultrasonic nebulisation (Cetac, $\mathrm{U}-5000 \mathrm{AT}^{+}$) was used to enhance detection limits.

\begin{tabular}{|l|l|}
\hline \multicolumn{2}{|c|}{ TABLE 2} \\
Optimised ICP-OES conditions for \\
the detection of V
\end{tabular}

\section{Reagents}

The water used for the preparation of all solutions was produced with a Millipore deionising system composed of two mixed resins, an activated carbon filter and a diaphragm filter. This water had a resistivity of $18 \mathrm{M} \Omega$.

- Ethylenediaminetetraacetic acid (disodium salt) (EDTA). SMM Chemicals (Pty) Limited. South Africa. $20 \mathrm{mmol} / \ell$ EDTA solution.

- Ammonium metavanadate $\left(\mathrm{NH}_{4} \mathrm{VO}_{3}\right)$. Aldrich Chemical Company, Inc. USA. $1 \mathrm{~g} / \ell \mathrm{V}(\mathrm{V})$ stock solution in $20 \mathrm{mmol} / \ell$ EDTA.

- V(IV) oxide sulphate $\left(\mathrm{VOSO}_{4} .5 \mathrm{H}_{2} \mathrm{O}\right)$. Merck. Germany. $1 \mathrm{~g} / \ell$ $\mathrm{V}(\mathrm{IV})$ solution in $20 \mathrm{mmol} / \ell$ EDTA.

- Eluant stock solutions: A. $0.5 \mathrm{~mol} / \ell \mathrm{Na}_{2} \mathrm{CO}_{3}$ (anhydrous, $\mathrm{BDH}$ Chemical Ltd., England) in $20 \mathrm{mmol} / \ell$ EDTA; B. $0.5 \mathrm{~mol} / \ell$ $\mathrm{NaHCO}_{3}$ (Saarchem (Pty) Ltd., South Africa) in $20 \mathrm{mmol} / \ell$ EDTA.

Reagents were Analytical Reagent Grade. Standards and working eluents were prepared by appropriate dilution of the stock solutions with $20 \mathrm{mmol} / \ell$ EDTA. All solutions were filtered through a 0.22 micron membrane filter. All samples were treated with EDTA to keep the EDTA concentration at $20 \mathrm{mmol} / \ell$, and then filtered.

\section{Sample preparation}

In the case of industrial samples, containing organic constituents which could damage the anion column such as Sasol Benfieldprocess samples analysed in this study, a simple chloroform extraction was used to remove organic components. This was done by extracting $10 \mathrm{~m} \ell$ of filtered sample with three $5 \mathrm{~m} \ell$ portions of chloroform.

\section{Results and discussion}

\section{The stabilisation of V(IV)}

The $\mathrm{V}^{4+}$ ion cannot exist in solution since the charge density is too large. Instead, the $\mathrm{VO}^{2+}$ ion is the dominant $\mathrm{V}(\mathrm{IV})$ species. The stability of the $\mathrm{VO}^{2+}$ ion depends on the prevailing conditions. In acidic solution and at low temperature, $\mathrm{VO}^{2+}$ can be kept for quite a long time. In alkaline solution, $\mathrm{VO}^{2+}$ species can be stored for about $4 \mathrm{~d}$ at room temperature. $\mathrm{V}(\mathrm{IV})$ is readily oxidised by oxygen in air in neutral or high $\mathrm{pH}$ media and the oxidation rate increases with increasing $\mathrm{pH}$ and temperature.

To prevent the oxidation of V(IV) species, a chelating ligand, such as EDTA, was chosen to complex it to form the V(IV)-EDTA anion complex, [VO(EDTA)] $]^{2-}$ (Komarova, et al., 1991). This complex has been well characterised, and it is very stable with a stability constant of, $\log \mathrm{K}=18.77$ (Inczedy, 1976). No sign of oxidation was observed after keeping the V(IV)-EDTA complex for over six months at room temperature. $\mathrm{V}(\mathrm{V})$ can also form a complex with EDTA. The stability constant of the V(V)-EDTA complex (Inczedy, 1976) $(\log K=18.1)$ is almost the same as for the $\mathrm{V}$ (IV)-EDTA complex. When the V(IV)-EDTA complex is mixed with $\mathrm{V}(\mathrm{V})$ species, $\mathrm{V}(\mathrm{V})$ would compete with $\mathrm{V}(\mathrm{IV})$-EDTA for EDTA. EDTA was also added to the $\mathrm{V}(\mathrm{V})$ stock solution. Thus, on mixing stock solutions to prepare samples containing both V(IV) and $\mathrm{V}(\mathrm{V})$, enough EDTA was present to stabilise both of the $\mathrm{V}$ complexes. The V(IV)-EDTA and the V(V)-EDTA complex, $\left[\mathrm{VO}_{2}(\text { EDTA })\right]^{3-}$ (Komarova, et al., 1991) are both anions, but they have different charges. The charge density properties of the two complexes form the basis for separating them on an anion exchange column. The V(IV)-EDTA complex elutes first, followed by the $\mathrm{V}(\mathrm{V})$-EDTA complex.

\section{Optimisation of experimental conditions}

\section{Column selection}

Three Dionex anion exchange guard columns AG4, AG5, and AG14, were evaluated for the separation of V(IV) and V(V) EDTA complexes. Figure 1 shows the change in resolution as a function of eluant concentration for each column.

Note: The resolution, R, between two adjacent peaks in this paper was calculated by the following equation (He et al., 1996):

$$
R=\frac{2 \Delta t}{1.699\left(w_{1}+w_{2}\right)}
$$

where:

$\Delta t$ is the difference in retention times of two adjacent peaks, and $\mathrm{w}_{1}$ and $\mathrm{w}_{2}$ are the half peak widths for two adjacent peaks.

The AG5 column showed the best resolution at all eluant strengths and was used in subsequent work.

\section{Optimisation of the eluant}

An eluant consisting of $2.8 \mathrm{mmol} / \ell \mathrm{Na}_{2} \mathrm{CO}_{3}$ and $2.2 \mathrm{mmol} / \ell \mathrm{NaHCO}$ is recommended by the manufacturer as standard for the AG5 column. For this eluant, however, broad and irregular peaks were observed for the $\mathrm{V}$ species. Addition of EDTA, to ensure that the V-EDTA complexes remained stable during the elution process, resolved this problem. In addition, EDTA competes with the VEDTA complexes for the exchange sites on the column, which increases the elution rate of the V-EDTA complexes, resulting in 


\begin{tabular}{|c|c|c|c|c|c|c|c|}
\hline \multicolumn{8}{|c|}{$\begin{array}{c}\text { TABLE } 3 \\
\text { The optimisation of EDTA concentration } \\
\text { Column: AG5 guard column. Flow rate: } 2.0 \mathrm{~m} / \mathrm{min}\end{array}$} \\
\hline \multirow{2}{*}{$\begin{array}{l}\text { EDTA } \\
\text { Conc. } \\
(\mathrm{mmol} / \ell)\end{array}$} & \multicolumn{3}{|c|}{ V(IV) } & \multicolumn{3}{|c|}{$V(V)$} & \multirow{2}{*}{$\begin{array}{l}\text { Reso- } \\
\text { lution }\end{array}$} \\
\hline & $\begin{array}{l}\text { R.T.* } \\
\text { (min) }\end{array}$ & $\begin{array}{l}W_{1 / 2} \\
(\mathrm{~min})\end{array}$ & $\begin{array}{l}\text { Peak } \\
\text { Area }\end{array}$ & $\begin{array}{c}\text { R.T. } \\
\text { (min) }\end{array}$ & $\begin{array}{c}W_{1 / 2} \\
\text { (min) }\end{array}$ & $\begin{array}{l}\text { Peak } \\
\text { Area }\end{array}$ & \\
\hline 5 & 0.386 & 0.0878 & 33869 & 1.286 & 0.2333 & 30263 & 3.30 \\
\hline 10 & 0.330 & 0.0750 & 33154 & 1.079 & 0.2150 & 32264 & 3.04 \\
\hline 15 & 0.334 & 0.0794 & 32264 & 0.929 & 0.1861 & 30096 & 2.64 \\
\hline 20 & 0.307 & 0.0739 & 32076 & 0.795 & 0.1589 & 30888 & 2.47 \\
\hline 25 & 0.317 & 0.0761 & 31875 & 0.761 & 0.1522 & 30410 & 2.29 \\
\hline
\end{tabular}

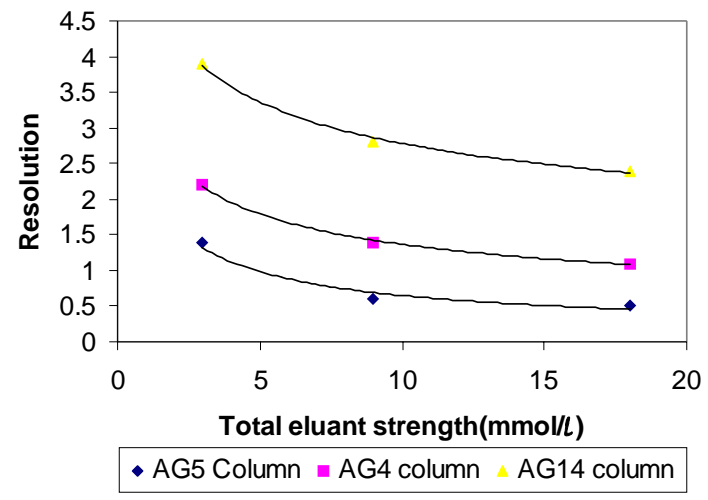

Figure 1

The change of resolution vs eluant concentration. EDTA concentration in eluant: $20 \mathrm{mmol} / \mathrm{l}$, flow rate: $2.0 \mathrm{ml} / \mathrm{min}$. Sample: A mixture of $10 \mathrm{mg} / \mathrm{lV}(\mathrm{IV})$ and $10 \mathrm{mg} / \mathrm{lV}(\mathrm{V})$

sharp and well-shaped peaks. Table 3 shows the results for the optimisation of the EDTA concentration.

The best resolution was obtained at lower EDTA concentrations, but the retention times were still too long ( $\geq 1 \mathrm{~min}$.) for $\mathrm{V}(\mathrm{V})$, and the peaks were also very broad. At too high EDTA concentration, poor resolution resulted, especially for high concentration samples. $20 \mathrm{mmol} / \ell$ EDTA yielded a rapid separation with acceptable peak broadening. This EDTA concentration was used in all subsequent work.

The concentration of each eluant component can affect the retention time (shown in Fig. 1), half peak width, and measurement sensitivity (peak area). It was necessary to optimise the eluant strength (the total carbonate and bicarbonate concentration) and the ratio of carbonate to bicarbonate in the eluant. Figure 2 shows how the eluant strength influences the resolution for different ratios of carbonate to bicarbonate.

Although, good resolution was obtained at low eluant strength, retention times were long and, consequently, the peaks were broad, especially the $\mathrm{V}(\mathrm{V})$ peak. An intermediate eluant strength of $16 \mathrm{mmol} / \ell$ and a carbonate to bicarbonate ratio of 1 to 3 were chosen for further work. By using this eluant, the corresponding resolution was about 1.8. Higher eluant strength was unfavourable for the

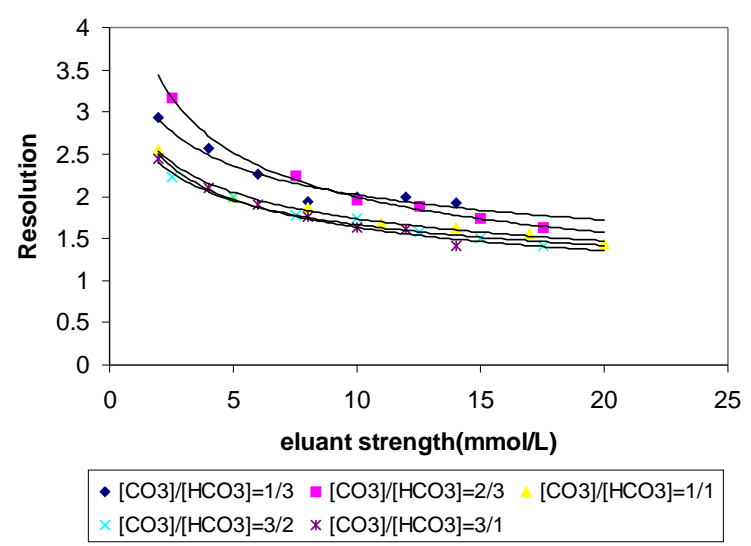

Figure 2

The change of resolution vs the eluant strength at different ratios of carbonate to bicarbonate in $20 \mathrm{mmol} / \ell$ EDTA.

Sample: $10 \mathrm{mg} / \mathrm{l} V(I V)$ and $10 \mathrm{mg} / \mathrm{l} V(\mathrm{~V})$. Flow rate: $2.0 \mathrm{m \ell} / \mathrm{min}$. Column: AG5 guard column.

measurement of high concentration samples as poor resolution would be obtained.

\section{Optimising flow rate}

Table 4 shows the results which were obtained from the measurement of a sample containing $10 \mathrm{mg} / \ell \mathrm{V}(\mathrm{IV})$ and $10 \mathrm{mg} / \ell \mathrm{V}(\mathrm{V})$ in $20 \mathrm{mmol} / \ell$ EDTA at different eluant flow rates using the optimum eluant.

According to the Van-Deemter theory, flow rate does not have a significant effect on resolution for an anion-exchange column. The nearly constant resolution shown in Table 4 is consistent with the theory. High flow rate reduces analysis time, but also reduces sensitivity (small peak area). Low flow rate can increase sensitivity, but also increases analysis time. An intermediate flow rate of $1.8 \mathrm{ml} / \mathrm{min}$ was selected as a compromise between analysis time and sensitivity.

\section{Optimising sample size}

Different sample sizes were evaluated and experimental data are shown in Table 5.

The difference in retention times was negligible. Small sample size results in good separation but poor sensitivity, while large 


\begin{tabular}{|c|c|c|c|c|c|c|c|}
\hline \multicolumn{8}{|c|}{$\begin{array}{c}\text { TABLE } 4 \\
\text { The effect of flow rate on the chromatographic separation of } \\
V(I V) \text { and } V(V) \text { for the AG5 column }\end{array}$} \\
\hline \multirow{2}{*}{$\begin{array}{l}\text { Flow } \\
\text { rate } \\
\mathrm{m} / / \mathrm{min}\end{array}$} & \multicolumn{3}{|c|}{ V(IV) } & \multicolumn{3}{|c|}{$V(V)$} & \multirow{2}{*}{$\begin{array}{l}\text { Reso- } \\
\text { lution }\end{array}$} \\
\hline & $\begin{array}{l}\text { R.T. } \\
(\min )\end{array}$ & $\begin{array}{l}W_{1 / 2} \\
(\mathrm{~min})\end{array}$ & $\begin{array}{l}\text { Peak } \\
\text { Area }\end{array}$ & $\begin{array}{c}\text { R.T. } \\
\text { (min) }\end{array}$ & $\begin{array}{c}\mathrm{W}_{1 / 2} \\
(\mathrm{~min})\end{array}$ & $\begin{array}{l}\text { Peak } \\
\text { Area }\end{array}$ & \\
\hline 1.0 & 0.610 & 0.1600 & 38396 & 1.630 & 0.3222 & 35881 & 2.04 \\
\hline 1.4 & 0.459 & 0.1094 & 34883 & 1.177 & 0.2322 & 32933 & 2.47 \\
\hline 1.8 & 0.356 & 0.0861 & 32887 & 0.908 & 0.1822 & 30873 & 2.42 \\
\hline 2.2 & 0.298 & 0.0717 & 29532 & 0.743 & 0.1506 & 28513 & 2.36 \\
\hline 2.6 & 0.255 & 0.0550 & 26566 & 0.617 & 0.1222 & 26718 & 2.40 \\
\hline 3.0 & 0.236 & 0.0544 & 24720 & 0.563 & 0.1106 & 24576 & 2.33 \\
\hline
\end{tabular}

\begin{tabular}{|c|c|c|c|c|c|c|c|}
\hline \multicolumn{8}{|c|}{$\begin{array}{l}\text { TABLE } 5 \\
\text { The effect of sample size on the chromatographic separation of } \mathrm{V}(\mathrm{IV}) \\
\text { and } \mathrm{V}(\mathrm{V}) \text {. Sample: } 10 \mathrm{mg} / \mathrm{V}(\mathrm{IV}) \text { and } 10 \mathrm{mg} / \ell \mathrm{V}(\mathrm{V}) \text {. Flow rate: } 1.8 \mathrm{~m} / \mathrm{min}\end{array}$} \\
\hline \multirow{2}{*}{$\begin{array}{l}\text { Sample } \\
\text { size } \\
(\mu \ell)\end{array}$} & \multicolumn{3}{|c|}{$\mathrm{V}(\mathrm{IV})$} & \multicolumn{3}{|c|}{$V(V)$} & \multirow{2}{*}{$\begin{array}{l}\text { Reso- } \\
\text { lution }\end{array}$} \\
\hline & $\begin{array}{l}\text { R.T. } \\
\text { (min) }\end{array}$ & $\begin{array}{l}\mathrm{W}_{1 / 2} \\
(\mathrm{~min})\end{array}$ & $\begin{array}{l}\text { Peak } \\
\text { Area }\end{array}$ & $\begin{array}{l}\text { R.T. } \\
\text { (min) }\end{array}$ & $\begin{array}{c}W_{1 / 2} \\
(\min )\end{array}$ & $\begin{array}{l}\text { Peak } \\
\text { Area }\end{array}$ & \\
\hline 30 & 0.349 & 0.0850 & 34998 & 0.884 & 0.1861 & 31467 & 2.32 \\
\hline 40 & 0.335 & 0.0806 & 39281 & 0.837 & 0.1978 & 38302 & 2.04 \\
\hline 50 & 0.364 & 0.0844 & 43600 & 0.914 & 0.2150 & 42281 & 2.16 \\
\hline 60 & 0.364 & 0.0867 & 49102 & 0.925 & 0.2278 & 48904 & 2.10 \\
\hline 70 & 0.371 & 0.0850 & 58770 & 0.908 & 0.2222 & 56351 & 2.06 \\
\hline 80 & 0.367 & 0.0858 & 72138 & 0.865 & 0.2250 & 70572 & 1.89 \\
\hline
\end{tabular}

sample size leads to good sensitivity but poor separation. For concentrated samples, too large a sample size can cause column overload. An intermediate sample size of $50 \mu \ell$ was used for all subsequent analyses.

\section{Detection limits and analytical working ranges}

Detection limits based on the average of the blank value plus three times its standard deviation, and analytical working ranges based on two times the best RSD of the calibration, were determined for the $\mathrm{V}$ species under the chromatographic conditions and ICP-OES conditions given in Tables 1 and 2 . The detection limits of V(IV) species were $0.02 \mathrm{mg} / \ell$ and $2 \mu \mathrm{g} / \ell$ by using a glass nebuliser and ultrasonic nebuliser, respectively. For $\mathrm{V}(\mathrm{V})$ species, the detection limits were $0.05 \mathrm{mg} / \ell$ and $2 \mu \mathrm{g} / \ell$ by using the glass nebuliser and ultrasonic nebuliser, respectively. The analytical working ranges for $\mathrm{V}(\mathrm{IV})$ was $2.0 \mathrm{mg} / \ell$ to $366 \mathrm{mg} / \ell$. The limits of quantitative determination for $\mathrm{V}(\mathrm{IV})$ were $2.0 \mathrm{mg} / \ell$ and $0.26 \mathrm{mg} / \ell$ by using a glass nebuliser and ultrasonic nebuliser, respectively. The limits of quantitative determination for $\mathrm{V}(\mathrm{V})$ were $4.1 \mathrm{mg} / \ell$ and $0.17 \mathrm{mg} / \ell$ by using the glass nebuliser and the ultrasonic nebuliser, respectively. The analytical working range for $\mathrm{V}(\mathrm{V})$ was $4.1 \mathrm{mg} / \ell$ to $310 \mathrm{mg} / \ell$. Two problems were observed in measuring the $\mathrm{V}(\mathrm{V})$-EDTA complex. The peak width increased with increasing concentration, while the retention time of the peak decreased. When using the AG5 guard column to analyse high concentration mixtures of $\mathrm{V}(\mathrm{IV})$ and $\mathrm{V}(\mathrm{V})$, poor resolution was obtained. In order to avoid peak overlap and to ensure good separation, a concentration range from $2 \mathrm{mg} / \ell$ to $100 \mathrm{mg} / \ell$ for $\mathrm{V}$ (IV), and $10 \mathrm{mg} / \ell$ to $100 \mathrm{mg} / \ell$ for V(V) is recommended for routine analysis. For high concentration samples, appropriate dilution is necessary.

\begin{tabular}{|c|l|l|}
\hline \multicolumn{2}{|c|}{$\begin{array}{l}\text { TABLE 6 } \\
\text { The effect of the V(IV)/V(V) concentration ratio }\end{array}$} \\
\hline & Ratio (R) & Result \\
\hline $\mathrm{V}(\mathrm{IV}) / \mathrm{V}(\mathrm{V})$ & $\mathrm{R}<12$ & $\begin{array}{l}\text { Quantitative results for V(IV) } \\
\text { and V(V) } \\
\text { Quantitative result for } \mathrm{V}(\mathrm{IV}) \\
\text { and qualitative result for } \mathrm{V}(\mathrm{V}) \\
\text { Only one peak for } \mathrm{V}(\mathrm{IV})\end{array}$ \\
\hline $\mathrm{V}(\mathrm{V}) / \mathrm{V}(\mathrm{IV})$ & $\mathrm{R}<10$ & $\begin{array}{l}\text { Quantitative results for } \mathrm{V}(\mathrm{V}) \\
\text { and V(IV) } \\
\text { Quantitative result for } \mathrm{V}(\mathrm{V}) \\
\text { and qualitative result for } \mathrm{V}(\mathrm{IV}) \\
\text { Only one peak for } \mathrm{V}(\mathrm{V})\end{array}$ \\
\hline & $\begin{array}{l}\mathrm{R}>20 \\
\mathrm{R}>15\end{array}$ & $\mathrm{R}<15$ \\
\hline
\end{tabular}


TABLE 7

Comparison of known concentrations with measured concentrations using the glass nebuliser. Correlation coefficient, $\mathbf{R}$, for V(IV), was $\mathbf{0 . 9 9 9 8}$, for V(V) it was 0.9982 (five standards calibration)

\begin{tabular}{|c|c|c|c|c|c|c|c|}
\hline \multirow{2}{*}{$\begin{array}{l}\text { Sample } \\
\text { No }\end{array}$} & \multicolumn{3}{|c|}{$\mathrm{V}(\mathrm{IV})$} & \multicolumn{3}{|c|}{$V(V)$} & \multirow{2}{*}{$\begin{array}{l}\text { Reso- } \\
\text { lution }\end{array}$} \\
\hline & $\begin{array}{c}\text { Known } \\
\mathrm{mg} / \ell\end{array}$ & $\begin{array}{l}\text { Measured } \\
\mathrm{mg} / \ell\end{array}$ & Recovery & $\begin{array}{c}\text { Known } \\
\mathrm{mg} / \ell\end{array}$ & $\begin{array}{c}\text { Measured } \\
\mathrm{mg} / \ell\end{array}$ & Recovery & \\
\hline 1 & 2.0 & $1.9 \pm 0.2$ & $95 \%$ & 10.0 & $12.0 \pm 0.6$ & $120 \%$ & 1.7 \\
\hline 2 & 5.0 & $4.6 \pm 0.5$ & $92 \%$ & 15.0 & $15.5 \pm 0.9$ & $103 \%$ & 1.5 \\
\hline 3 & 20.0 & $19.6 \pm 1.2$ & $98 \%$ & 30.0 & $29.0 \pm 0.9$ & $97 \%$ & 1.2 \\
\hline 4 & 50.0 & $51.6 \pm 1.1$ & $103 \%$ & 60.0 & $56.7 \pm 2.4$ & $94 \%$ & 1.0 \\
\hline 5 & 100.0 & $99.3 \pm 3.1$ & $99 \%$ & 100.0 & $101.8 \pm 3.0$ & $102 \%$ & 0.7 \\
\hline
\end{tabular}

\begin{tabular}{|c|c|c|c|c|c|c|c|}
\hline \multicolumn{8}{|c|}{$\begin{array}{l}\text { TABLE } 8 \\
\text { Comparison of known concentrations with measured concentrations for various } V(I V) \text { to } V(V) \\
\text { ratios using the glass nebuliser. Correlation coefficient, } R \text {, for } V(I V) \text {, was } 0.9988 \text {, for } V(V) \text {, } \\
\text { it was } 0.9997 \text { (seven standards calibration) }\end{array}$} \\
\hline \multirow{2}{*}{$\begin{array}{c}\text { Sample } \\
\text { No }\end{array}$} & \multicolumn{3}{|c|}{ V(IV) } & \multicolumn{3}{|c|}{$\mathrm{V}(\mathrm{V})$} & \multirow{2}{*}{$\begin{array}{l}\text { Reso } \\
\text { lution }\end{array}$} \\
\hline & $\begin{array}{c}\text { Known } \\
\mathrm{mg} / \ell\end{array}$ & $\begin{array}{c}\text { Measured } \\
\mathrm{mg} / \ell\end{array}$ & Recovery & $\begin{array}{c}\text { Known } \\
\mathrm{mg} / \ell\end{array}$ & $\begin{array}{l}\text { Measured } \\
\mathrm{mg} / \ell\end{array}$ & Recovery & \\
\hline 1 & $3.0^{*}$ & $3.8 \pm 0.6$ & $127 \%$ & 8.0 & $8.0 \pm 0.6$ & $100 \%$ & 1.7 \\
\hline 2 & 100.0 & $102.9 \pm 2.0$ & $103 \%$ & 10.0 & $8.9 \pm 0.5$ & $89 \%$ & 0.9 \\
\hline 3 & 80.0 & $76.7 \pm 2.1$ & $96 \%$ & 15.0 & $15.2 \pm 0.9$ & $101 \%$ & 1.4 \\
\hline 4 & 40.0 & $39.2 \pm 1.1$ & $98 \%$ & 20.0 & $20.3 \pm 1.1$ & $102 \%$ & 1.3 \\
\hline 5 & 40.0 & $38.2 \pm 2.0$ & $97 \%$ & 40.0 & $41.0 \pm 1.3$ & $102 \%$ & 1.1 \\
\hline 6 & 20.0 & $19.6 \pm 1.4$ & $98 \%$ & 60.0 & $60.7 \pm 1.4$ & $101 \%$ & 0.9 \\
\hline 7 & 10.0 & $9.8 \pm 0.8$ & $98 \%$ & 80.0 & $79.2 \pm 1.7$ & $99 \%$ & 0.8 \\
\hline 8 & 8.0 & $8.7 \pm 1.9$ & $109 \%$ & 100.0 & $99.8 \pm 3.5$ & $100 \%$ & 0.8 \\
\hline
\end{tabular}

\section{Interference study}

\section{The ratio of $V(I V)$ and $V(V)$}

When the concentration ratio of the two species is large, they interfere with each other during measurement. When the main species at high concentration is measured at reduced photomultiplier sensitivity, the detection of the other species at low concentration during the same measurement cycle is impaired. The results of the ratio study are shown in Table 6.

The reason why the ratio of $\mathrm{V}(\mathrm{IV}) / \mathrm{V}(\mathrm{V})$ is larger than the ratio of $\mathrm{V}(\mathrm{V}) / \mathrm{V}(\mathrm{IV})$ is that the $\mathrm{V}(\mathrm{IV})$ peak is narrower than the $\mathrm{V}(\mathrm{V})$ peak and it can be integrated more accurately than the $\mathrm{V}(\mathrm{V})$ peak.

\section{Other elements and ions}

At the chosen measurement wavelength of $309.311 \mathrm{~nm}$, only the nearby $\mathrm{Nb}$ line at $309.418 \mathrm{~nm}$ can cause a spectral interference on the $\mathrm{V}$ measurement. Al concentrations higher than $100 \mathrm{mg} / \ell$, can also interfere with $\mathrm{V}$ measurement, especially for $\mathrm{V}(\mathrm{V})$ measurement. This can be attributed to the fact that the $\mathrm{Al}$ emission line at $309.271 \mathrm{~nm}$ causes a background enhancement on the $\mathrm{V}$-emission line. The common anions, such as: $\mathrm{F}^{-}, \mathrm{Cl}^{-}, \mathrm{Br}^{-}, \mathrm{CH}_{3} \mathrm{COO}^{-}, \mathrm{NO}_{2}^{-}$, $\mathrm{NO}_{3}^{-}, \mathrm{SO}_{4}^{2-}$, and $\mathrm{HPO}_{4}^{2-}$ do not cause interference.

\section{Accuracy}

The method was applied to samples with known concentrations of the $\mathrm{V}$ species. The results are shown in Tables 7 to 9 . The confidence intervals were based on four replicate measurements and a confidence level of $95 \%$.

A comparison of the known concentration with the measured concentration shows a good agreement. These results show that the method can be applied successfully to measure $\mathrm{V}$ species in water samples.

\section{Effect of sample pH}

Because the $\mathrm{pH}$ range could be expected to be large in industrial samples, the effect of sample $\mathrm{pH}$ on analytical results were investigated. Four self-prepared samples with the same concentration $(20 \mathrm{mg} / \ell \mathrm{V}(\mathrm{IV})$ and $20 \mathrm{mg} / \ell \mathrm{V}(\mathrm{V}))$, but with different $\mathrm{pH}$ values, were analysed after adding $20 \mathrm{mmol} / \ell$ EDTA. The concentrations determined for the two species are summarised in Table 10. The results show no systematic variation as a result of $\mathrm{pH}$ variation. It proves that the method can be utilised to determine $\mathrm{V}$ species in samples which may have a large range of $\mathrm{pH}$ values, from pH 3.0 to $\mathrm{pH} 10.5$. 
TABLE 9

Comparison of known concentrations with measured concentrations for different ratios of V(IV) to V(V) using the ultrasonic nebuliser. Correlation coefficient, $R$, for V(IV), was $\mathbf{0 . 9 9 9 3}$, and for V(V), it was 0.9994 (seven standards calibration)

\begin{tabular}{|c|c|c|c|c|c|c|c|}
\hline \multirow{2}{*}{$\begin{array}{c}\text { Sample } \\
\text { No }\end{array}$} & \multicolumn{3}{|c|}{$\mathrm{V}(\mathrm{IV})$} & \multicolumn{3}{|c|}{$V(V)$} & \multirow{2}{*}{$\begin{array}{l}\text { Reso- } \\
\text { lution }\end{array}$} \\
\hline & $\begin{array}{c}\text { Known } \\
\mathrm{mg} / \ell\end{array}$ & $\begin{array}{c}\text { Measured } \\
\mathrm{mg} / \ell\end{array}$ & Recovery & $\begin{array}{c}\text { Known } \\
\mathrm{mg} / \ell\end{array}$ & $\begin{array}{c}\text { Measured } \\
\mathrm{mg} / \ell\end{array}$ & Recovery & \\
\hline 1 & 0.2 & $0.13 \pm 0.06$ & $65 \%$ & 0.8 & $0.74 \pm 0.17$ & $92 \%$ & 1.2 \\
\hline 2 & 0.6 & $0.65 \pm 0.02$ & $108 \%$ & 6.0 & $6.19 \pm 0.04$ & $103 \%$ & 1.1 \\
\hline 3 & 1.0 & $1.00 \pm 0.08$ & $100 \%$ & 8.0 & $8.39 \pm 0.14$ & $105 \%$ & 0.8 \\
\hline 4 & 2.0 & $2.02 \pm 0.09$ & $101 \%$ & 4.0 & $4.04 \pm 0.10$ & $101 \%$ & 1.1 \\
\hline 5 & 3.0 & $2.96 \pm 0.08$ & $99 \%$ & 2.0 & $2.02 \pm 0.12$ & $101 \%$ & 1.2 \\
\hline 6 & 4.0 & $4.11 \pm 0.24$ & $103 \%$ & 0.5 & $0.42 \pm 0.09$ & $84 \%$ & 1.5 \\
\hline 7 & 5.0 & $4.92 \pm 0.78$ & $98 \%$ & 10.0 & $9.79 \pm 2.12$ & $98 \%$ & 1.2 \\
\hline
\end{tabular}

\begin{tabular}{|c|c|c|c|c|c|}
\hline \multicolumn{6}{|c|}{$\begin{array}{c}\text { TABLE } 10 \\
\text { Effect of sample pH }\end{array}$} \\
\hline \multirow[t]{2}{*}{$\begin{array}{l}\text { Sample } \\
\text { No. }\end{array}$} & \multirow[t]{2}{*}{ pH } & \multicolumn{2}{|c|}{$\begin{array}{c}\mathrm{V}(\mathrm{IV}) \text { concentration } \\
(\mathrm{mg} / \ell)\end{array}$} & \multicolumn{2}{|c|}{$\begin{array}{l}\mathrm{V}(\mathrm{V}) \text { concentration } \\
(\mathrm{mg} / \ell)\end{array}$} \\
\hline & & Known & Measured & Known & Measured \\
\hline 1 & 10.2 & 20.0 & $20.9 \pm 0.3$ & 20.0 & $20.5 \pm 0.5$ \\
\hline 2 & 8.9 & 20.0 & $20.0 \pm 0.4$ & 20.0 & $19.7 \pm 0.4$ \\
\hline 3 & 7.0 & 20.0 & $20.6 \pm 0.7$ & 20.0 & $20.3 \pm 0.7$ \\
\hline 4 & 3.6 & 20.0 & $20.8 \pm 0.5$ & 20.0 & $20.0 \pm 0.4$ \\
\hline
\end{tabular}

\begin{tabular}{|c|c|}
\hline \multicolumn{2}{|c|}{ TABLE 11 } \\
The preparation of simulated \\
Sasol samples \\
Volume 2 mol/ $/\left(\mathrm{NH}_{4}\right)_{2}$ S added/m $\ell$ \\
\hline Testing sample & Volume \\
\hline Sample 1 & 0 \\
Sample 2 & 2 \\
Sample 3 & 4 \\
Sample 4 & 6 \\
\hline
\end{tabular}

\section{TABLE 12}

V(IV) and V(V) content of simulated Sasol samples. Reproducibility was based on three replicate determinations and a confidence level of $95 \%$

\begin{tabular}{|l|c|c|c|c|}
\hline \multirow{2}{*}{$\begin{array}{l}\text { Test } \\
\text { sample }\end{array}$} & ICP & \multicolumn{3}{|c|}{ IC } \\
\cline { 2 - 5 } & $\begin{array}{c}\text { Total V Conc. } \\
(\mathbf{m g} / \ell)\end{array}$ & $\begin{array}{c}\mathbf{V}(\mathbf{I V}) \\
(\mathbf{m g} / \ell)\end{array}$ & $\begin{array}{c}\mathbf{V}(\mathbf{V}) \\
(\mathbf{m g} / \ell)\end{array}$ & $\begin{array}{c}\text { Total V Conc. } \\
(\mathbf{m g} / \ell)\end{array}$ \\
\hline Sample 1 & $48.10 \pm 1.80$ & $<$ Detection limit & $49.10 \pm 1.59$ & $49.58 \pm 1.59$ \\
Sample 2 & $47.88 \pm 1.27$ & $76 \pm 0.47$ & $43.25 \pm 2.17$ & $49.01 \pm 2.64$ \\
Sample 3 & $47.63 \pm 1.42$ & $13.68 \pm 1.89$ & $36.52 \pm 2.54$ & $50.20 \pm 4.43$ \\
Sample 4 & $47.13 \pm 0.78$ & $21.06 \pm 0.92$ & $28.27 \pm 1.20$ & $50.33 \pm 2.12$ \\
\hline
\end{tabular}

\section{The analysis of industrial samples}

The method was evaluated by analysing eight samples obtained from different stages in the Benfield process for $\mathrm{CO}_{2}$ removal used by the synthetic fuel manufacturer, Sasol. In this process the V(IV)/ $\mathrm{V}(\mathrm{V})$ redox couple is used to protect the inner surfaces of steel pipes against corrosion.

The samples from Sasol were likely to contain two V species, $\mathrm{V}(\mathrm{V})$ and $\mathrm{V}(\mathrm{IV})$ in various ratios depending on the process phase. To simulate these different phases where different $\mathrm{V}(\mathrm{IV}) / \mathrm{V}(\mathrm{V})$ ratios would occur, a Benfield sample with an approximate concentration of $5000 \mathrm{mg} / \ell \mathrm{V}(\mathrm{V})$ buffered with $350 \mathrm{mmol} / \ell \mathrm{K}_{2} \mathrm{CO}$ and $100 \mathrm{mmol} / \ell \mathrm{KHCO}_{3}$ at $\mathrm{pH} 10.5$ was prepared. The sample was summarises the results.

treated with different amounts of $\left(\mathrm{NH}_{4}\right)_{2} \mathrm{~S}$ to reduce the $\mathrm{V}(\mathrm{V})$ to $\mathrm{V}(\mathrm{IV})$. This produced solutions with different $\mathrm{V}(\mathrm{IV}) / \mathrm{V}(\mathrm{V})$ ratios. $\left(\mathrm{NH}_{4}\right)_{2} \mathrm{~S}$ was added to $0.5 \mathrm{~m} \ell$ sample which was then diluted to $50 \mathrm{~m} \ell$ in a volumetric flask with $20 \mathrm{mMEDTA}$. The volume of $\left(\mathrm{NH}_{4}\right)_{2} \mathrm{~S}$ solution added is summarised in Table 11.

All test samples were filtered through 0.22 membrane filters and measured by direct ICP-OES to obtain the total $\mathrm{V}$ concentration and by the proposed IC-ICP-OES system to obtain the species concentration and the total $\mathrm{V}$ by summation. Table 12

As expected, the V(IV) content increased with increasing amounts of reducing agent. The total $\mathrm{V}$ content obtained by the two methods was comparable, with the IC-ICP-OES results somewhat closer to the expected $50 \mathrm{mg} / \ell$. This suggests that the proposed method will give accurate results in the measurement of industrial effluent and industrial process samples.

\section{Chloroform extraction}

Since the Sasol samples could contain organic constituents which could damage the anion column, a simple chloroform extraction was used to remove the organic components. To determine whether 
this extraction can cause loss of $\mathrm{V}$ or not, the samples obtained from Sasol were analysed for total V content by ICP-OES before and after extraction. The $\mathrm{pH}$ value of the samples was about 11 . Test samples were prepared by 100 -fold dilution with deionised water in a $50 \mathrm{~m} \ell$ volumetric flask. $3.0 \mathrm{~m} \ell 65 \% \mathrm{HNO}_{3}$ was added to the flask to adjust the test sample's $\mathrm{pH}$ value to that of the standards. The total V concentration in 3 of the 8 Sasol samples was also determined by an independent analytical laboratory, Modderfontein Laboratory Services(MLS) in Johannesburg by ICP-OES. The three samples were prepared as follows: $0.5 \mathrm{~m} \ell$ of raw sample was diluted with $50 \mathrm{~m} \ell$ deionised water acidified with $7.52 \mathrm{~m} \ell 65 \%$ $\mathrm{HNO}_{3}$, then heated for $20 \mathrm{~min}$ in a water bath at $60^{\circ} \mathrm{C}$, filtered through a 0.22 micron membrane filter, transferred to a $100 \mathrm{~m} \ell$ volumetric flask and made up to the mark with deionised water. The total $\mathrm{V}$ concentration before and after extraction and the results obtained from MLS after correction for dilution are compared in Table 13.

Statistical analysis shows no difference between the results before and after extraction, and the MLS measurements show good agreement with the results obtained in this work. Consequently, all test samples prepared for the IC-ICP-OES system were diluted

\begin{tabular}{|c|c|c|c|}
\hline \multicolumn{4}{|c|}{$\begin{array}{c}\text { TABLE } 13 \\
\text { The comparison of total vanadium concentration } \\
(\mathrm{mg} / \ell)\end{array}$} \\
\hline $\begin{array}{c}\text { Sample } \\
\text { No. }\end{array}$ & $\begin{array}{c}\text { Before extraction } \\
100 \text {-fold dilution }\end{array}$ & $\begin{array}{l}\text { After extraction } \\
100 \text {-fold dilution }\end{array}$ & $\begin{array}{l}\text { MLS measuremen } \\
100 \text {-fold dilution }\end{array}$ \\
\hline 1 & 51.23 & 50.74 & \multirow{8}{*}{68} \\
\hline 2 & 52.16 & 50.84 & \\
\hline 3 & 62.05 & 63.06 & \\
\hline 4 & 71.08 & 69.38 & \\
\hline 5 & 70.11 & 71.28 & \\
\hline 6 & 42.30 & 43.37 & \\
\hline 7 & 61.32 & 61.16 & \\
\hline 8 & 65.08 & 64.14 & \\
\hline
\end{tabular}

100 -fold with $20 \mathrm{mmol} / \ell$ EDTA after triple extraction with chloroform. No nitric acid was added, because the $\mathrm{pH}$ values of prepared Sasol samples were between 8 9, within the working $\mathrm{pH}$ range for the proposed method. Double filtration through 0.22 micron membrane filters was performed to prevent the column from blocking. To evaluate possible matrix effects caused by complex Benfield samples, test samples were determined by the standard addition method. The results are summarised in Table 14.

Agreement between the total V concentrations shown in Table 13 and the sum of the speciation results shown in Table 14 is excellent.

\section{Conclusion}

The proposed IC-ICP-OES system offers an accurate, precise and interference-free method for the simultaneous determination of $\mathrm{V}(\mathrm{IV})$ and $\mathrm{V}(\mathrm{V})$ in industrial and water samples. The method is fast (less than one minute per run), simple and relatively inexpensive since it utilises a guard column instead of an expensive analytical column.

The following should, however, be kept in mind:

- At high concentration levels, Al broaden the $\mathrm{V}(\mathrm{V})$ peak, because its emission line $(309.271 \mathrm{~nm})$ is close to the $\mathrm{V}$ emission line at $309.311 \mathrm{~nm}$. Proper dilution of samples may solve this problem.

- With high concentration of $\mathrm{V}$ in samples, good baseline resolution can be achieved by using a AG5 guard column coupled with AS5 analytical column, or the AG5 column only can be used after proper dilution.

- At low V concentrations, an ultrasonic nebuliser is recommended instead of a glass nebuliser.

\section{Acknowledgements}

The authors thank the NRF for financial support, and Sasol for providing test samples.

\begin{tabular}{|c|c|c|c|c|c|c|}
\hline \multicolumn{7}{|c|}{$\begin{array}{c}\text { TABLE } 14 \\
\text { Comparison of } \mathrm{V} \text { concentrations in Benfield samples determined using externa } \\
\text { standards and the standard addition method. Number of replicate } \\
\text { determinations is } 3 .\end{array}$} \\
\hline \multirow{2}{*}{$\begin{array}{l}\text { Test } \\
\text { sample } \\
\text { No. }\end{array}$} & \multicolumn{3}{|c|}{ External standards } & \multicolumn{3}{|c|}{ Standard addition } \\
\hline & $\begin{array}{l}\mathrm{V}(\mathrm{IV}) \\
(\mathrm{mg} / \ell)\end{array}$ & $\begin{array}{c}\mathrm{V}(\mathrm{V}) \\
(\mathrm{mg} / \ell)\end{array}$ & $\begin{array}{l}\text { Total } \\
(\mathrm{mg} / \ell)\end{array}$ & $\begin{array}{l}\mathrm{V}(\mathrm{IV}) \\
(\mathrm{mg} / \ell)\end{array}$ & $\begin{array}{c}\mathrm{V}(\mathrm{V}) \\
(\mathrm{mg} / \ell)\end{array}$ & $\begin{array}{l}\text { Total } \\
(\mathrm{mg} / \ell)\end{array}$ \\
\hline 1 & $16.18 \pm 0.46$ & $36.35 \pm 0.05$ & $52.53 \pm 0.52$ & & & \\
\hline $2^{* * *}$ & Undetectable & $49.42 \pm 0.12$ & $49.42 \pm 0.12$ & & & \\
\hline $3^{* *}$ & Undetectable & $64.78 \pm 1.94$ & $64.78 \pm 1.94$ & $1.84^{*}$ & 64.04 & 64.04 \\
\hline 4 & $18.67 \pm 2.28$ & $51.84 \pm 1.91$ & $70.51 \pm 4.19$ & 18.76 & 53.64 & 72.40 \\
\hline 5 & $18.32 \pm 1.46$ & $48.80 \pm 2.18$ & $67.12 \pm 3.64$ & 20.24 & 52.78 & 73.02 \\
\hline $6^{* *}$ & Undetectable & $41.40 \pm 1.59$ & $41.40 \pm 1.59$ & $1.74^{*}$ & 48.08 & 48.08 \\
\hline 7 & $17.24 \pm 1.76$ & $44.48 \pm 3.05$ & $61.72 \pm 4.81$ & & & \\
\hline 8 & $18.12 \pm 2.93$ & $41.51 \pm 1.94$ & $59.63 \pm 4.87$ & & & \\
\hline
\end{tabular}




\section{References}

BALAJI BK, SARAVANAKUMAR G, MURUGESAN P and MISHRA G(1998) A modified catalytic-photometric method for the determination of vanadium in chloride rich hydro-geochemical samples. Talanta 461299.

BOSQUE-SENDRA JM, VALENCIA MC and BOUDRA S (1998) Speciation of vanadium(IV) and vanadium(V) with Eriochrome Cyanine $\mathrm{R}$ in natural waters by solid phase spectrophotometry. Fresenius J. Anal. Chem. 36031.

BROWNING EMD (1961) Toxicity of Industrial Metal. Publishing Co. Butterworth, Great Britain.

CHAKRABORTY R and DAS AK (1994) Determination of vanadium by ETAAS using chromium nitrate as chemical modifier. Fresenius' J. Anal. Chem. 349774.

CHAUHAN RS and KAKKAR LR (1992) Extractive separation and photometric determination of vanadium with Benzoylacetone. Bull. Chem. Soc. Japan 651033.

COTTON FA and WILKINSON G (1988) Advanced Inorganic Chemistry (5th edn.) Publishing Co., Wilner, New York, USA.

DE BEER H and COETZEE PP (1994) Vanadium speciation by ion chromatography. Fresenius' J. Anal. Chem. 348806.

DUPONT V, AUGER Y, JEANDEL C and WARTEL M (1991) Determination of vanadium in seawater by inductively coupled plasma atomic emission spectrometry using chelating resin column preconcentration. Anal. Chem. 63520.

ELVINGSON K, CRANS DC and PETTERSSON L (1997) Speciation in vanadium bioinorganic system. 4. Interactions between vanadate, adenosine, and imidazole - An aqueous potentiometric and ${ }^{51} \mathrm{~V}$ NMR study. J. Am. Chem. Soc. 1197005.

ENSAFI AA and NADERI B (1997) Catalytic determination of ultra trace amounts of vanadium with detection by linear sweep voltammetry. Fresenius' J. Anal. Chem. 358480.

FRANKENBERGER A, BROOKS RR and HOASHI M (1991) Determination of vanadium in steels and geological materials by liquid-liquid extraction and graphite furnace atomic absorption spectrometry. Anal. Chim. Acta. 246359.

GRUDPAN K and NACAPRICHA D (1991) Flow-injection radiorelease analysis for vanadium. Anal. Chim. Acta. 246329.

HE XL, ZHAO SZ and WU SH (1996) Analytical Chemistry. Beijing, P.R. China.

HIRAYAMA K, KAGEYAMA S and UNOHARA N (1992) Mutual separation and preconcentration of vanadium(V) and vanadium(IV) in natural waters with chelating functional group immobilized silica gels followed by determination of vanadium by inductively coupled plasma atomic emission spectrometry. Analyst. 11713.

INCZEDY J (1976) Analytical Applications of Complex Equilibria. Publishing Co., Ellis Horwood, United Kingdom.
IRANPOOR N, MALEKI N, RAZI S and SAFAVI A (1992) Spectrophotometric determination of vanadium in different oxidation states with pyrogallol. Talanta 39 (3) 281.

KAWAKUBO S, OGIHARA K and IWATSUKI M (1995) Catalytic spectrofluorimetric determination of vanadium using oxidation of ophenylenediamine with bromate in the presence of gallic acid. Analyst. 1202719.

KOMAROVA TV, OBREZKOV ON and SHPIGUN OA (1991) Ion chromatographic behaviour of anionic EDTA complexes of vanadium(IV) and vanadium(V). Anal. Chim. Acta 25461.

MIURA J (1990) Determination of trace amounts of vanadium in natural waters and coal fly ash with 2-(8-quinolylazo)-5-(demethylamino)phenol by reversed-phase liquid chromatography-spectrophotometry. Anal. Chem. 621424.

MIURA J, HOSHINO H and YOTSUYANAGI T (1990) Determination of trace amounts of vanadium in air samples with 2-(8-quinolylazo)-5$\mathrm{N}, \mathrm{N}$-diethylaminophenol by reversed-phase liquid chromatography. Anal. Chim. Acta. 233121.

MURTHY GVR, REDDY TS and RAO SB (1989) Extraction and simultaneous spectrophotometric determination of vanadium(IV) and vanadium $(\mathrm{V})$ in admixture with 2-hydroxyacetophenone oxine. Analyst. 114493

SANDER S and HENZE G (1996) Adsorptive stripping voltammetric determination of vanadium as chloranilic acid complex. Fresenius' $J$. Anal. Chem. 356259.

SERRAT FB and MORELL GB (1994) Colorimetric method for the determination of vanadium with tannic acid in water and oils. Fresenius' J. Anal. Chem. 349717.

SHAH N, DESAI MN, MENON SK and AGRAWAL YK (1991) Ionexchange separation and spectrophotometric determination of vanadium in environmental samples. Talanta 38 (6) 649.

TAYLOR MJC, MARSHALL GD, WILLIAMS SJS, VAN STADEN JF and SALING C (1996) The determination of vanadium(V) in the presence of vanadium(IV) using 4-(2-pyridylazo)resorcinol in a flowinjection manifold. Anal. Chim. Acta 329 (3) 275.

VUKOMANOVIC DV and VANLOON GW (1994) Voltammetric determination of vanadium with adsorptive preconcentration of the pyrocatechol violet complex. Talanta 41 (3) 387.

YAMANE T, OSADA Y and SUZUKI M (1998) Continuous flow system for the determination of trace vanadium in natural waters utilizing inline preconcentration/separation coupled with catalytic photometric detection. Talanta 45583.

YAMAN M and GUCER S (1994) Determination of vanadium in biological matrices by flame atomic absorption spectrometry with activated carbon enrichment. Fresenius' J. Anal. Chem. 350504.

ZUCCHI C, FORNERIS M, MARTINEZ L, OISINA R and MARCHEVSKY E (1998) Sensitive spectrophotometric determination of vanadium with hydrogen peroxide and 2-(5-chloro-2-pyridylazo)-5dimethylaminophenol after extraction with N-benzoyl-N-phenylhydroxylamine. Fresenius' J. Anal. Chem. 360128. 